\title{
THE REFORESTATION OF CUT-OVER AND IDLE LANDS IN NEW YORK
}

\section{BULLETIN}

OF

\section{New York}

\section{State Colleze of Forestry}

AT

\section{Syracuse University}

Published Quarterly by the University,

\author{
Syracuse, N. Y.
}




\section{TRUSTEES.}

\section{Ex OFFicio.}

Chancellor JAMEs Roscoe DAY, S. T. D., D. C. L., LL.D. .......................... Syracuse, $N$. $Y$.

Hon. ANDREW S. DRAPER, LL.B., LL.D., Comviissioner of Education....................

Albany, N. Y.

APPOINTED BY THE GOVERNOR.

Hon. George E. VAN KenNen, Chairman Conserwation Commission ......................

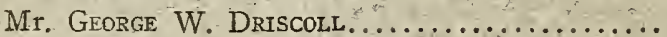
Hon. JoHN R. Clancy

Ogdensburg, N. Y. Syracuse, N. Y. Syracuse, N. Y.

\section{Chosen by the University Trustees.}

Hon. HENDRICK S. HOLDEN. Mr. James M. Gilbert.

Mr. Georger J. SAgER

Mir. WILFRED W PORTER

Hon. Louts Marshais

Mr. EDWIN R. REDHEAD
Syracuse, N: Y. Syracuse, N. Y. Syracuse, N. Y. Syracuse, H. Y. New York, N. Y. Fulton, N. Y:

\section{OFFICERS OF THE BOARD.}

President ........................... Hon. LOUIS MARShall. Vice-President ....................... Hon. JoHn R. Clancy. Secretary and Treasurer................ WILFRED W. PoRTER. 


\title{
BULLETIN
}

\author{
or \\ NEW YORK STATE \\ COLLEGE OF FORESTRY \\ AT \\ SYRACUSE UNIVERSITY
}

THE REFORESTATION OF CUT-OVER AND IDLE LANDS IN NEW YORK

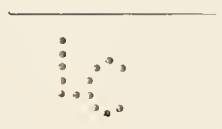

SYRACUSE

1913 
SD2.54 .583 
FACULTY OF THE NEIV YORK STATE COLLEGE OF FORESTRI AT SIRACUSE UNIVERSITY.

\author{
JAMES ROSCOE DAI, S. T. D., D. C. L., LL.D., \\ Chancellor of the Unizersity.
}

HUGH POTTER BAKER, M. F. (Yale I90 4); D. Oec. (Munich I9IO), DEAN ,

Professor of Silviculture.

FRANK F. MOON, B. A. (Amherst College Igor); M. F. (Tale I909),

Professor of Forest Engineering.

PHILIP TRIPP COOLIDGE, A. B. (Harvard I905); M. F. (Yale I907),

Director of Ranger School; Professor of Forestry.

EDWARD F. MCCARTHY, B. S. (University of Michigan I9II) :

M. F. (University of Michigan I9II),

Assistant Professor of Forest Products.

JOHN WALLACE STEPHEN, B. A. (University of Michigan);

M, S. (University of Michigan I907),

Assistant Professor of Silviculture.

NELSON CORTLANDT BROWN, B. A. (Yale Igo6); M. F. (Yale I908),

Assistant Professor of Forest Utilization.

REUBEN PARKER PRICHARD, B. S. (Dartmouth I907) M. F. Yale (igog),

Instructor in Forestry at Ranger School.

RUSSELL TAYIOR GHEEN, B. S. F. (Penn State I9I2), Student Assistant in Forestry.

EDITH E. HAITH, B. L. E. (Syracuse I9I2),

Librarian.

LILLIAN M. LANG,

Secretary to the Dean. 


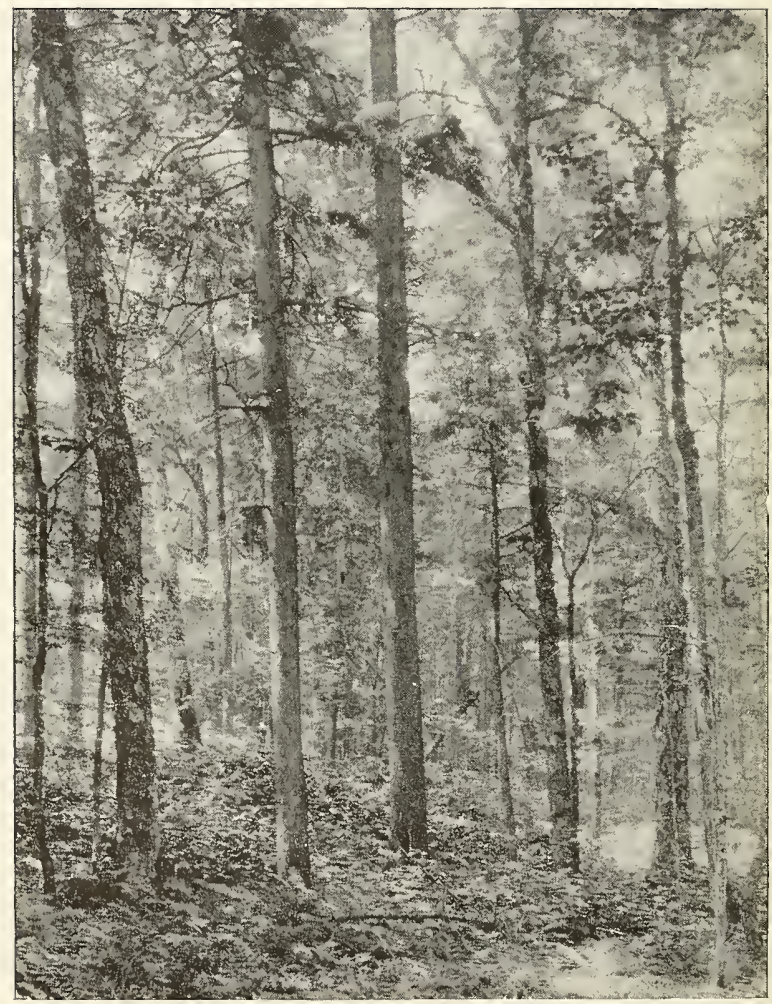

Photo by Hugh P. Baker.

There are Valuable Forests upon State Lands in NEW YORT.

Virgin Forest in Township to in the Adirondacks. Much of the larger Spruce, Fir and Beech and Birch are over-ripe and should be removed to insure the proper development of the future forest. 


\section{THE REFORESTATION OF CUT OVER AND IDLE LANDS IN NEW IORK.}

\section{A Large Part of New York Better Suited to Forestry than to Agriculture.}

Out of the $34,000,000$ of acres in the State of New York over 35 per cent or $12,000,000$ of acres are better suited for the growing of timber than for any other purpose. This is the verdict of the Census Bureau for the Great State of New York. It is difficult indeed to appreciate what this large area of land means, but if it were one unbroken forest, it would cover the States of Rhode Island, Connecticut, Massachusetts and extend for forty miles across the southern part of Vermont and New Hampshire. Or it would cover in our own State practically all of the section north of the New York Central Railroad.

Statistics show also that out of the 22,000,000 of acres enclosed within the farms of the State, but I5,000,000 are actually in agricultural crops. This means that there are $7,000,000$ of idle acres in the farms of New York which should be made productive. It is probable that not all of this large area is actually nonagricultural, but without question there is an area larger than the State of Massachusetts enclosed within our farms and permanently non-productive. Of the $12,000,000$ of acres outside of the farms and referred to above, it has been shown that less than half contains merchantable timber, about four million and a half of the twelve millions of acres are covered with more or less valuable growth but non-merchantable; there are then nearly two millions of acres with no valuable growth at all, really in the form of waste lands.

\section{New YoRK has no Real Waste Land.}

It is a misnomer in a way to call these essential forest lands waste lands. To-day New York is land poor in a sense and yet these very lands will in time become a source of large profit to the State. Forest land in Europe not nearly as well adapted to the production of forests as much of the forest areas of New York is producing as high as $\$ 3$ to $\$ 5$ per acre per year. It may be many years before our waste lands will be producing so high an annual return as this but with reasonable care these lands will soon begin to be productive and in time will bear a large share of the burden of the support of this great Commonwealth. 


\section{Little or no Valuable Tree Growth on Denuded Lands.}

What is the condition of these denuded lands at the present time? Over much of the area we will find a scattering growth of brush and inferior tree species occupying the ground or we may find old, abandoned pastures gradually giving up to the extension of the forests about them. Usually they produced a valuable timber crop in the past and are capable of such production again. If left to herself Nature might succeed in time in re-establishing a good forest. However, the often repeated statement that if we will simply protect our cutover lands, as they now exist, from fire, that they will soon come up to valuable forests again, is seldom true. Where a reasonable number of the right kind of mother trees have been left on the ground, Nature may in tine reforest the surface with a fair growth of timber. There are very extensive areas in New York where all of the valuable trees have been cut or destroyed by fire and it will take many years indeed to bring back anything in the way of a satisfactory forest. Over such areas it will be necessary to do a certain amount of planting before the right kind of forest can be established. As the forest lands of New York lie largely in the zone of the maximum development of the conifers, which are usually evergreens. the future forests of the State will without doubt be made up largely of rapid growing conifers such as some of the pines and spruces.

\section{Second Growth Hardwood Often Worthless.}

Over lands which formerly produced a hardwood forest, Nature often re-establishes a second forest in a comparatively short time. These second growth hardwood or sprout forests are formed readily from the stumps of trees and in a measure are independent of seed trees for reproduction. It is very different with the conifers or evergreens which with one or two exceptions are incapable of reproducing by means of sprouts. As certain of our conifers are the most rapid growing trees which we can put onto the land and have a timber that is very desirable for use in the industries, it is probable that much of our future forests will be evergreen or coniferous. There is too much land in the State to-day covered with poor, worthless, second growth hardwoods. These should be removed entirely and replaced by seedlings of the evergreens. Much quicker returns will be gotten by this clear cutting and planting than can be expected from the present growth on the ground, even though some attempt is made to improve it. After the coniferous forest is once well established it may 


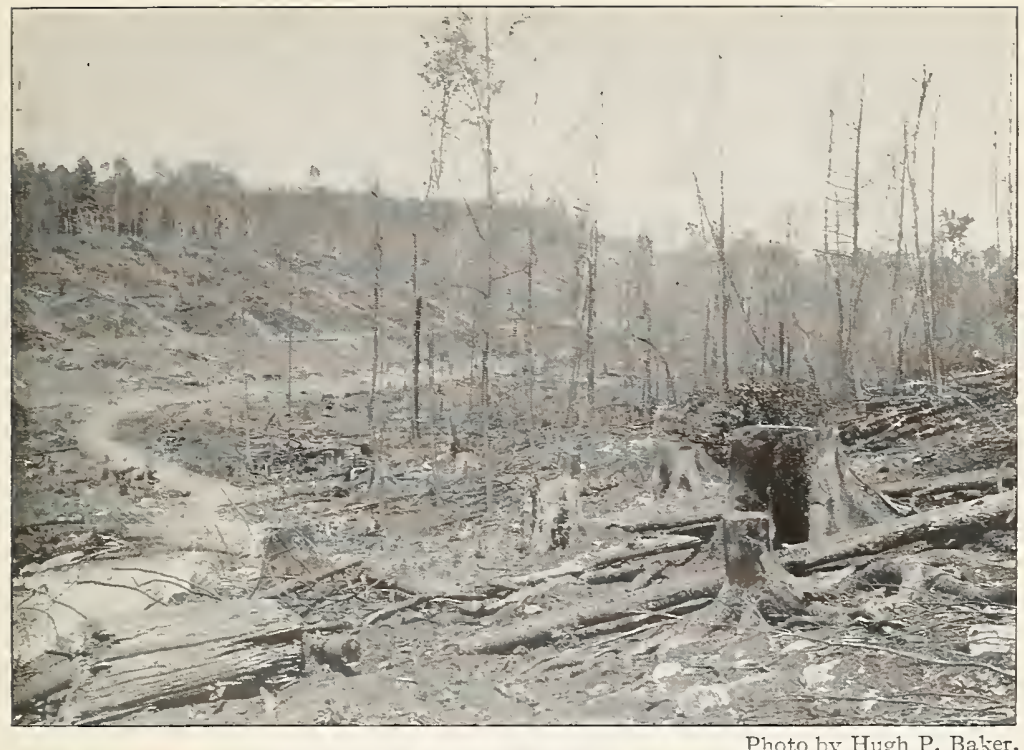

After the lumberman has come and gone and fire has swept over annually for a few years, the soil formed by centuries of forest cover disappears. It may take centuries to bring the soil back again and make the land as able to produce the forests as when the virgin forest was cleared off.

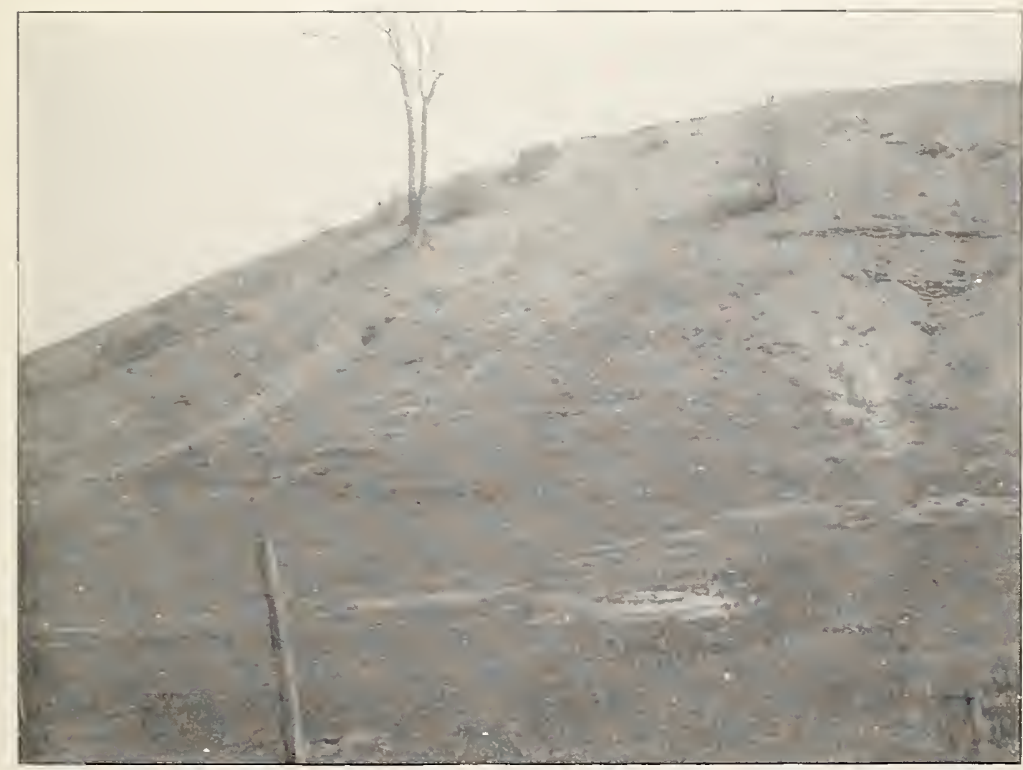

Courtesy of Conservation Commission.

A bit of valuable forest land in New York that should never have been denuded. Why should this land lie idle for almost a century waiting for nature to crown it with forests? While it is idle it is not only unproductive but because of erosion is a menace to agricultural lands below and to streams and rivers. 
be possible to use methods of natural reproduction that will make unnecessary any large amount of planting. The reforestation of idle or barren lands by replanting is expensive and it is hoped that as Forestry develops in the State that less and less of it will be necessary. The fact that over 3,000,000 acres or nearly io per cent of the States are covered with no growth of value should be cause enough for active agitation and real beginnings in reforestation. The great area of ten per cent of the State should be returning from six to eight millions of dollars annually with only very ordinary forest management. In the County of Onondaga alone there are 70,000 acres of unimproved land and it is very safe to say that over 15,000 of these must be replanted if they are to be made in any way productive. They will be absolutely nonproductive if left barren as they are not adapted to agriculture of any kind.

\section{Idle Lands Within Farms of the State.}

Too much of the real idle land of this State is found enclosed within our farms. There are very few farms which do not have from Io to 40 acres that are better suited for growing timber than for any agricultural crop. Often, if these lands are stripped of their tree growth they will soon begin to wash and at once become a menace to the more valuable lands lying below them, therefore, when the timber is cut, the land should be replanted at once to forest trees. One objection to planting a forest is that it takes considerable time for the trees to become of value. This should have less weight in the consideration of the farmer than it has. It is coming to be recognized that thrifty growing trees have a definite value however small they are. We do not expect or want good agricultural land to be used for the production of trees, but a few acres of drifting sand or rocky hillside will give a bad impression of the farm as a whole. A prospective buyer will be greatly influenced in his valuation of the property by the barren and unsightly portions, perhaps more strongly influenced than by the actual amount of fertile land, thus it will be seen that a good growth of forests on the idle lands of our farms would be of value from an aesthetic standpoint and regardless in a way of the actual value of the growing stock. With the constant demand for poles and posts and other timbers on the farm, it will be possible to draw very early indeed upon the planted timber for a return. Then too, many of the farms in the State could be made to produce as a bi-product obtained by thinning from the planted forest 


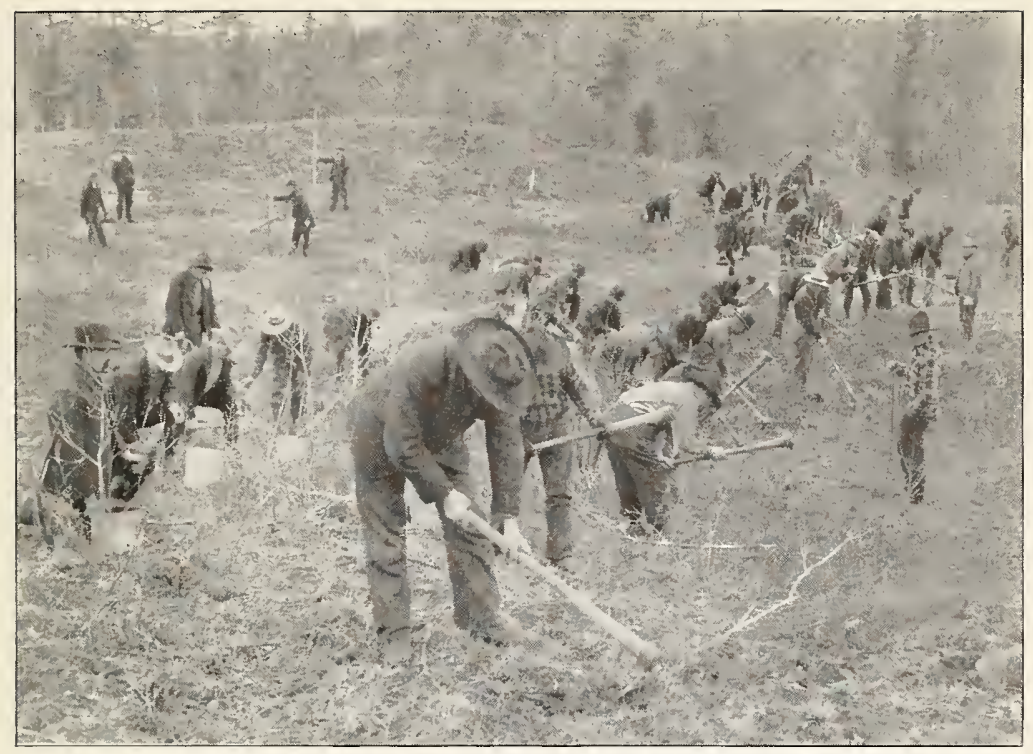

Courtesy of Conservation Commission.

Experimental plantations being put out by the State on State lands. Forests are necessary to protect the soil, conserve the water supply and by planting where nature will not restock the ground easily we grow what we want, where we want it, more of it, with a greater value, in a shorter time, and, all things considered, at less expense.

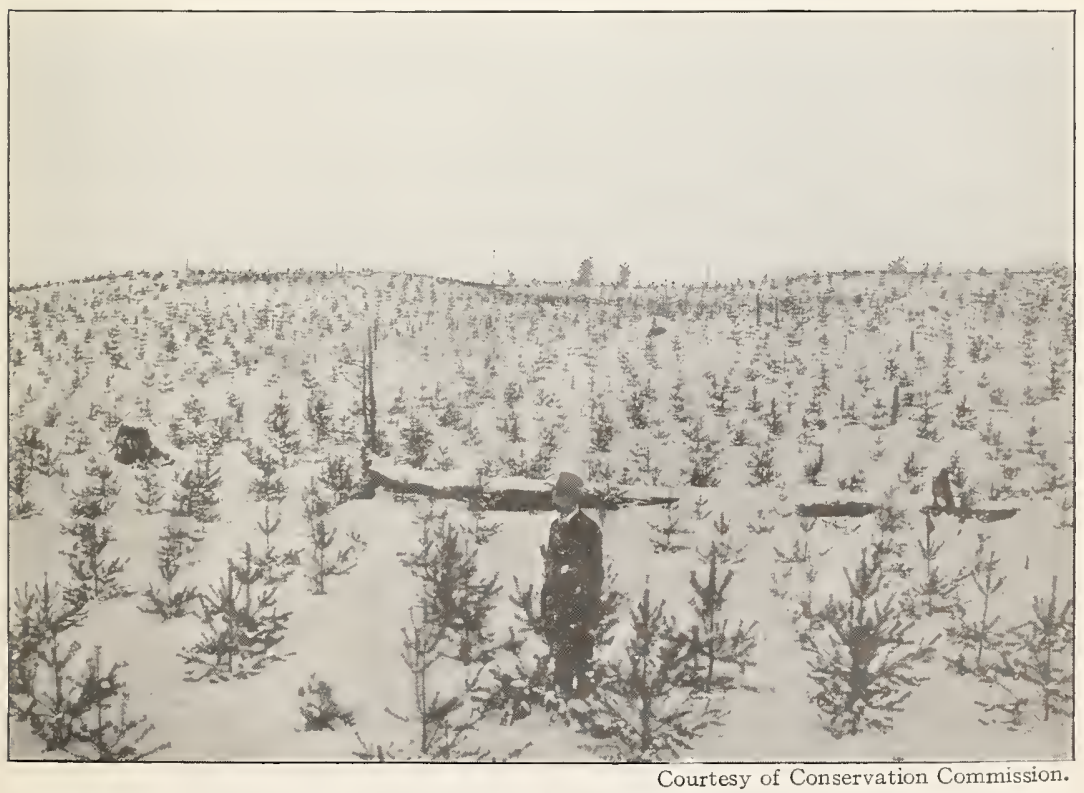

Results of planting on State lands in Adirondacks. Instead of paper birch, trembling aspen and pincherry occupying this ground for the next twenty-five years, we have a uniform stand of thrifty pine with every square rod occupied. Such results can be gotten on idle lands anywhere in the State. 
enough Christmas trees annually to more than pay for the thinning and in a sense pay a considerable part of the cost of the plantation itself. The same is true of larger bodies of cut-over or idle land belonging either to the States or to large land owners. In their desolate barren condition, they are of no value to anyone and they are a disgrace to a State as progressive and prosperous as the State of New York. The only way to make them valuable is to start a forest upon them which in time will produce an annual crop of timber. Far-sighted business men are beginning to see the value of young timber and are buying lands covered with promising young growth and holding them until they have a market value.

\section{Idle Lands Made Prodective by Planting of Forest Trees.}

It is a fair question to ask each farmer in the State and each land owner whether he has such idle lands as are described above and whether it is not worth while to grow a crop that will not only increase the sale value of the property but will annually make the land more and more productive. Trees are the only crop which will do this and leave the land in better condition than at the start.

Take for example the case of John Mathers who has a rarm in Onondaga County. It contains 20 acres of land in the form of a rocky hillside that is practically useless for agriculture. This piece has a slope greater than Io per cent. and therefore should never have been cut-over and left clear in the first place because of the danger of severe erosion. It has long been a question with Mr. Mathers as to what use to make of this barren nillside. As it stands to-day it is a constant expense for taxes besides it depreciates the value of the entire farm because of its unsightly appearance. Every rain cuts deeper and deeper the gulleys on the hillside and carries gravel and rocks farther down over the cultivated fields. The New York State College of Forestry at Syracuse University would like to step in here and co-operate with Mr. Mathers by making a plan or giving suggestions for planting of this waste area with such rapid growing evergreens as the White or Norway Pine or the Norway Spruce. Mr. Mathers being a practical man will want to know the expense and the approximate returns of such a plantation before undertaking the work.

The expense of such a plantation as Mr. Mathers would want to make would consist of the cost of planting, interest on value of land, taxes on land and timber all carried at compound interest to the time of harvesting. The net returns will be the gross returns less the total 
expense. With lands worth $\$ 4$ per acre, cost of planting $\$ 7$ per acre and money at 4 per cent., it will result as follows for White Pine:

\begin{tabular}{|c|c|c|c|c|c|}
\hline & Age of plantation in years. & $\begin{array}{l}\text { Gross } \\
\text { returns. }\end{array}$ & Expenses. & $\begin{array}{l}\text { Net } \\
\text { returns. }\end{array}$ & $\begin{array}{c}\text { Net } \\
\text { return } \\
\text { per acre } \\
\text { and year. }\end{array}$ \\
\hline $\begin{array}{l}25 \\
30\end{array}$ & $\begin{array}{l}\$ 6 \text { per } \mathrm{MI} \ldots \ldots \ldots \ldots \ldots \ldots \\
\text { (Stumpage value) } \ldots \ldots \ldots \ldots \ldots\end{array}$ & $\begin{array}{rr}\$ 40 & 50 \\
75 & 00\end{array}$ & $\begin{array}{r}\$ 2750 \\
3760\end{array}$ & $\begin{array}{r}\$ 1300 \\
38 \quad 40\end{array}$ & $\begin{array}{rr}\text { so } & 52 \\
1 & 28\end{array}$ \\
\hline $\begin{array}{l}35 \\
40 \\
45\end{array}$ & $\begin{array}{l}\text { ss per } \mathrm{i} \\
\text { (Stumpage value) } \ldots \ldots \ldots \ldots\end{array}$ & $\begin{array}{ll}195 & 00 \\
262 & 40 \\
324 & 80\end{array}$ & $\begin{array}{rr}52 & 51 \\
72 & 20 \\
108 & 66\end{array}$ & $\begin{array}{ll}142 & 66 \\
190 & 20 \\
216 & 20\end{array}$ & $\begin{array}{ll}4 & 07 \\
4 & 75 \\
4 & 80\end{array}$ \\
\hline $\begin{array}{l}50 \\
55\end{array}$ & $\begin{array}{l}\$ 10 \text { per } \mathrm{MI} \ldots \ldots \ldots \ldots \ldots \ldots \\
\text { (Stumpage value) } \ldots \ldots \ldots \ldots \ldots \ldots\end{array}$ & $\begin{array}{l}46500 \\
505 \quad 50\end{array}$ & $\begin{array}{ll}157 & 85 \\
228 & 05\end{array}$ & $\begin{array}{ll}307 & 15 \\
277 & 45\end{array}$ & $\begin{array}{ll}6 & 14 \\
5 & 04\end{array}$ \\
\hline $\begin{array}{l}60 \\
65\end{array}$ & $\begin{array}{l}\$ 12 \text { per } \mathbf{~} 1 . \ldots \ldots \ldots \ldots \ldots \ldots \ldots \\
\text { (Stumpage value) } \ldots \ldots \ldots \ldots \ldots \ldots\end{array}$ & $\begin{array}{ll}532 & 00 \\
566 & 00\end{array}$ & $\begin{array}{ll}315 & 68 \\
433 & 28\end{array}$ & $\begin{array}{ll}216 & 32 \\
132 & 72\end{array}$ & $\begin{array}{ll}3 & 60 \\
2 & 04\end{array}$ \\
\hline
\end{tabular}

This table will bear careful study as it is taken from a large number of studies made from the growth of planted White Pine under conditions very similar to those existing in the county. What does the table show? It indicates that land of poor quality is capable of producing valuable returns. $U_{p}$ to 25 or 30 years of age, the diameter is small and the material has to be used for poles or fuel or pulp and boxboards. The stumpage value is around $\$ 6$ per thousand feet. From that age on it puts on timber rapidly and the quality of the timber is ever better. It will bring $\$ \$$ per thousand feet and yield a net return at the age of 35 to 50 of over $\$ 4$ per acre per year. At about 60 years of age it yields the highest return which is $\$ 6$ per acre per year. From the time the timber has passed 35 years of age until it reaches 60 , it can be cut at any time and will return a greater value per acre than the value of the land if used in any other way. It shows further that one can afford to pay somewhat more than $\$ 4$ an acre for land that is now idle and reforest it with every assurance that it will make a profitable long time investment. Approximately the same results as described for the White Pine can be obtained by using Norway Pine, Norway Spruce, Western Red Fir and such hardwoods as the Ash and Red Oak. These last must be put into somewhat different soils and different locations than the conifers described above and yet the results of plantations of these species show that very excellent returns can be gotten even on the worst bits of idle land in the farms of the State. 


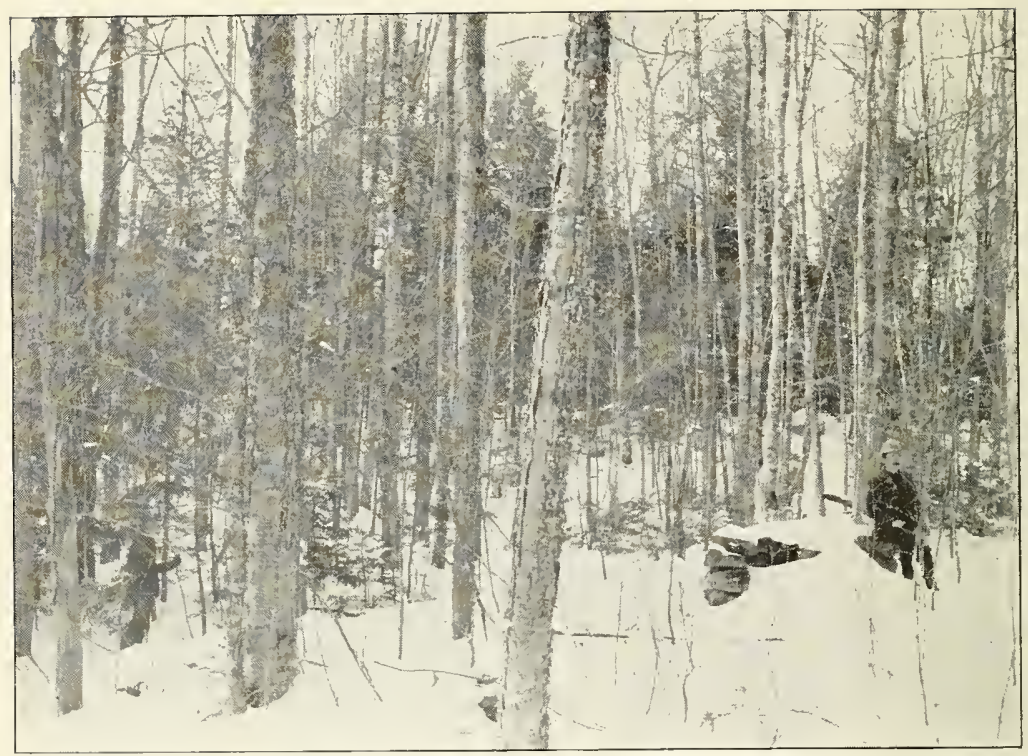

Courtesy of Conservation Commission.

Forest conditions on a cut-over and abandoned tract fifty years after self-seeding has been accomplished. Note the variety of species many of which are inferior both in kind and quality. Proper management would remove the undesirable species and increase by two or three times the growth of the right kind of trees.

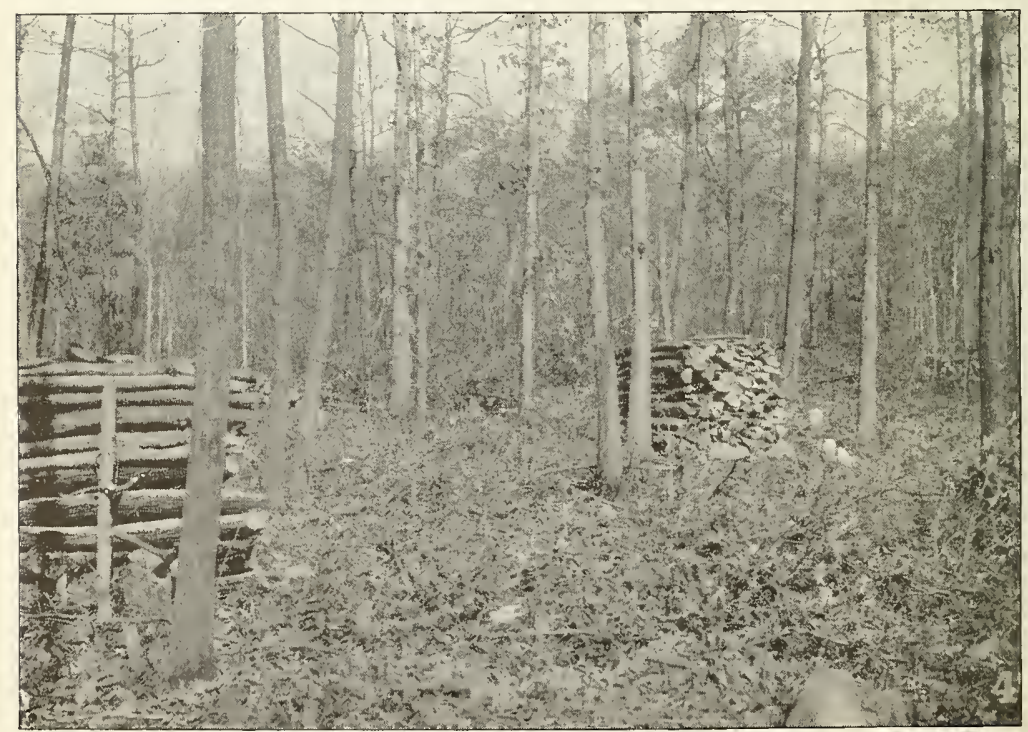

Courtesy of W. C. Shepard.

A second growth sprout and seedling woodlot properly thinned. Poor and worthless kinds of trees taken out and the better ones given a chance to greatly increase their growth. 
The Improvement of Woodlands and Farm Woodlots.

It may be that there is already a sort of forest growth on these idle lands. If there is, it will pay to handle it properly. Thus far in this State, we have been using the accumulation of years of growth without thought for future growth. Little or no provision is being made for a second crop. Where a second growth is coming on, too little thought is being given to it. No forest can be continued permanently unless satisfactory reproduction is secured and proper conditions maintained.

The grove or woodlot, as timber on the farm is usually called, may be so open that the trees retain their limbs well down towards the ground, making it impossible to produce anything but knotty timber. It may be so open that leaf mold, so necessary to proper conditions of growth will not decompose properly and grass and weeds and brush will come in and occupy the ground. It is all too often in such neglected condition that reproduction is impossible and then the only thing that can be done is to cut off the present growth and start a new forest from the beginning. It may be possible at times to thicken up the woodlot by underplanting or to change the condition to such an extent that self-seeding will be successful. This natural reproduction will often take place easily if stock is kept out of the woodlot. No reproduction can be expected if land is pastured. The wood lot may be so dense that the trees crowd each other so severely that growth is checked and the trees do not develop. Eventually a certain number must die and the others continue to maturity. This struggle which causes the death of many young trees may be lessened in intensity to the great benefit of the woodlot by taking out enough trees so that those which are left will put on a much larger amount of wood because of additional space and light.

Many woodlots are made up of a great variety of species, a large proportion of which are of little value and should be removed to give room to the more valuable sorts. The composition and thus the value of an entire woodlot may be greatly improved and increased by simply taking out the so-called forest weeds, such as Ironwood, Red Maple, Dogwood, Juneberry, Hawthorn and others.

Unfortunately nearly all of the conditions described above are found in woodlots in every county in the State. Several may be found in any one farm forest. Look through woodlot or timberland! Is there a tree there under 25 years of age? If not, is it not because you have pastured it or have allowed surface fires to run through annually? 


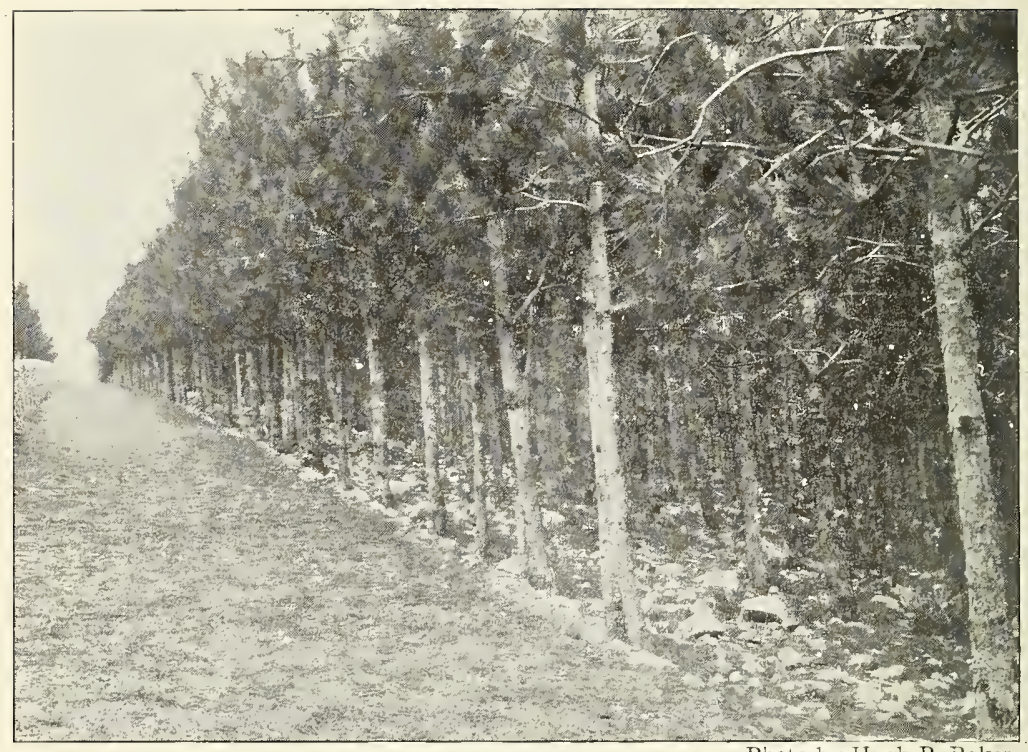

Ploto by High P. Baker.

Very barren and waste hillsides in the Karst in Southern Austria being brought back to productive forest conditions through the planting of trees. Nowhere in New York are there more barren hills than these which are being so successfully reforested. Climatic conditions are much more favorable in New York than in region shown in above picture.

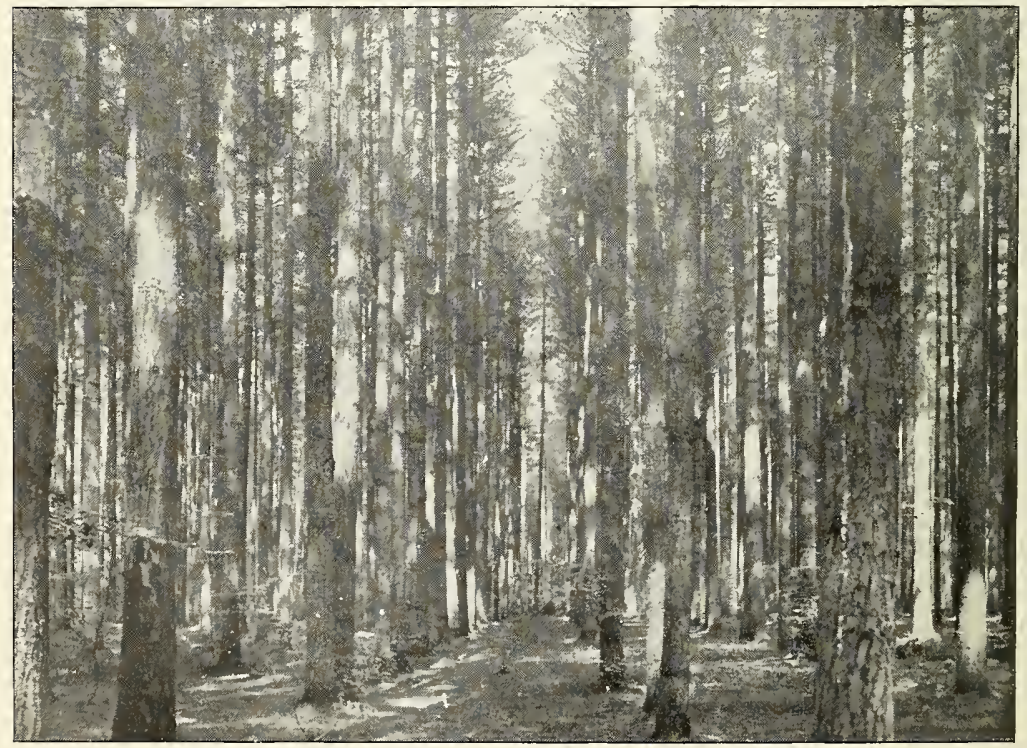

Photo by Hugh P. Baker.

Planted White Pine in Germany on very sandy soil. This is not the result of superior soil or climatic conditions or of an extended period of time, but results from the proper handling of the forest from the beginning. 
If 10 tree has succeeded in starting in the last 25 years, what will be the condition of your woodland in the future? Many thousands of acres of forest land are being culled annually with no thought of the future stand. Every tree removed makes the stand thinner and allows of the incoming of more grass and brush and of more windfalls. No farm can afford to be without a woodlot upon it both becanse of the pleasure and comfort of it and because the material you can take from it annually, makes it well worth while from a financial standpoint.

The trees and the method of planting that would be suitable for one farm or forest property may not be applicable at all to the adjoining one. Conditions of soil, slope and general situation vary so much that each area to be reforested is in a sense a problem by itself. It will often save both time and money not to plant without knowing thoroughly as to the nature of soil and trees best adapted to these soils.

Landes Planted to Forests or Maintained as Forests May be ExEMPTED FRON TAXATION.

A State Law passed in 1912 provides for exemption from taxes upon certain classes of lands which are planted with forest trees or which are maintained as permanent woodlots or timber lands. For copy of this Law and information as to the procedure to be followed in listing forest lands for exemption from or reduction in taxes address the Conservation Commission, Albany, New York. It is strongly urged that owners of idle or forested lands throughout the State take advantage of the help offered by this Law which seeks to overcome some of the unfairness of the older methods of taxing forest lands and puts them more nearly on the same basis as true agricultural lands.

The New York State College of Forestry at Syracuse University is a State Institution established and supported for educational work throughout the entire State. It is ready to co-operate with any land owner who wishes to begin planting or who is desirous of improving his woodlot or timberland by practical forestry methods. Applications for advice and co-operation should be addressed to The New York State College of Forestry at Syracuse University, Syracuse, New York. These applications will be placed on file and as rapidly as possible will be taken up in groups by counties and assigned to the expert in charge of this work. The only expense connected with the inspection will be the necessary traveling expenses and maintenance 
from the nearest previous inspection. By the system of grouping by counties this amounts to very little and would probably never exceed five dollars. If the amount of land to be examined is over 300 acres and reasonable assurance is given that the plans of management will be carried out the inspection will be made free of charge. Groups of land owners in the same neighborhood may unite and by bringing their combined areas to 300 or more acres have plans made at no cost. 


\section{THE NEW YORK STATE COLLEGE OF FORESTRY}

AT

\section{SYRACUSE UNIVERSITY}

Designated and supported by the State as the Institution for Educational Work in Forestry in New York,

\section{OFFERS AT}

\section{SYRACUSE UNIVERSITY}

A Five-Year Professional Course, leading to degrees of Bachelor of Science (B. S.) and Master of Forestry (M. F.).

A RANGER COURSE of one and two years given on the College Forest in the Adirondacks, Wanakena, New York. Practical courses of training leading to such positions as guards, rangers, forest estate managers, tree planting experts and nursery foremen.

As a part of its state-wide educational work, the College offers to make plans for the protection and management of timberlands and woodlots for the reforestation of cut-over and barren areas. Where the timberland or woodlots or barren areas are between 300 and 1,000 acres and where there is reasonable assurance that plans will be carried out, they will be made at no expense to the owner. Where there is less than the above amount,-it will be necessary to have owners pay expenses of traveling and sustenance while the plan is being made. Owners of smaller tracts may combine and by bringing the area to 10o or more acres, have plans made without cost.

The College invites correspondence at any time as to its educational work or for information regarding the protection and management of forests or woodlots, tree planting, forest insects and tree diseases, and timber treating. 
